Jakub Marusik*

\title{
Konstytucyjne zasady sprawiedliwości, równości i powszechności opodatkowania a system ulg, zwolnień, odliczeń, kwot wolnych i kosztów w podatku dochodowym
}

\begin{abstract}
System of tax relief, tax exemption, tax deduction, tax-free amount and tax costs in income tax in light of the constitutional principles of fair taxation, equality and universality of taxation: The article investigates the legal framework for tax privileges within the Polish income tax regulations in light of principle of fair taxation (fiscal justice). The paper begins with an overview of fiscal justice and different categories of privileges (tax relief, tax exemption, etc.). In the next section, the author addresses the question of relation between these privileges and the principle of fair taxation. The final part of the article focuses on assessment of detailed regulation related to fiscal justice. The author argues that the current system of tax privileges in general complies with the requirements of fair taxation, however there is a need to introduce some changes.
\end{abstract}

Słowa kluczowe: zasada sprawiedliwości podatkowej · zasada równości opodatkowania · zasada powszechności opodatkowania $\cdot$ podatek dochodowy $\cdot$ ulga podatkowa $\cdot$ zwolnienie podatkowe $\cdot$ odliczenie podatkowe $\cdot$ kwota wolna od podatku

Keywords: principle of fair taxation - fiscal justice - equality of taxation · universality of taxation $\cdot$ income tax $\cdot$ tax relief $\cdot$ tax exemption $\cdot$ tax deduction · tax-free amount

* Doradca podatkowy, doktorant na Wydziale Prawa i Administracji Uniwersytetu Łódzkiego; e-mail: jakubmarusik@wp.pl.

\section{Wstęp}

Głównym zamysłem, który legł u podstaw niniejszego opracowania, jest ukazanie idei stosowania, mających swe źródło w postanowieniach Konstytucji RP, zasad sprawiedliwości, równości i powszechności opodatkowania na tle funkcjonowania w ramach podatku dochodowego unormowań tworzących system 
ulg, zwolnień, odliczeń, kwot wolnych oraz kosztów podatkowych. Istotna przy tym jest w szczególności kwestia, jaki jest wzajemny stosunek między koniecznością zapewnienia efektywności opodatkowania z jednej strony a realizacją postulatów wynikających $\mathrm{z}$ obowiązywania zasady sprawiedliwości podatkowej z drugiej strony. Warto się również pochylić nad zagadnieniem dotyczącym tego, czy przyjęte obecnie w zakresie przywilejów podatkowych rozwiązania prawne służące opodatkowaniu dochodów osobistych w sposób wszechstronny służą realizacji szeroko pojmowanej zasady sprawiedliwości podatkowej czy też może stanowią swoisty wyjątek lub też odstępstwo od przytoczonej reguły. Już na wstępie należy zaznaczyć, że zagadnienie dotyczące zasady sprawiedliwości ma niesłychanie istotne znaczenie właśnie na gruncie podatku dochodowego, bowiem to w przypadku tej daniny podatnik jest w pełni świadomy nakładania na niego obciążenia, które odczuwa w sposób bezpośredni.

\section{Fundamenty idei sprawiedliwości podatkowej oraz reguł równości i powszechności opodatkowania na gruncie podatku dochodowego}

Punktem wyjścia dla wszelkich rozważań dotyczących istoty analizowanego zagadnienia powinno być przede wszystkim ukazanie samej koncepcji sprawiedliwości podatkowej. Jej źródeł należy upatrywać w szerszej teorii sprawiedliwości prawa, rozumianej między innymi jako dążenie do naturalnego porządku. Funkcjonując zgodnie z tym porządkiem, każdy człowiek ma możliwość egzekwowania swoich przyrodzonych, przynależnych mu uprawnień ${ }^{1}$, w warunkach zakładających jednakowe traktowanie jednostek należących do tej samej kategorii działowej². Sprawiedliwość w koncepcji nauki prawa finansowego - z uwagi na brak jednorodnego i obiektywnego układu odniesienia jest natomiast odnoszona przede wszystkim do kwestii wyznaczenia zakresu ciężaru podatkowego spoczywającego na podatnikach i koncentruje się wokół problemów związanych z uwzględnianiem reguł powszechności i równomierności obciążania podatkiem podmiotów stosunków prawno-podatkowych ${ }^{3}$. Niekiedy zakłada się przy tym, że precyzyjne i jednoznaczne zdefiniowanie pojęcia sprawiedliwości podatkowej jest niewykonalne, bowiem odnosi się ono również do zagadnień etycznych, które są niejednolicie pojmowane i oceniane przez poszczególne jednostki czy też grupy społeczne ${ }^{4}$. Trudność w tym za-

${ }^{1}$ Szerzej zob. J. Rawls, Teoria sprawiedliwości, Wydawnictwo Naukowe PWN, Warszawa 2018; J. Ziembiński, O pojmowaniu sprawiedliwości, Instytut Wydawniczy Daimonion, Lublin 1992, i cytowana tam literatura.

2 Zob. Ch. Perelman, O sprawiedliwości, Państwowe Wydawnictwo Naukowe, Warszawa 1959 , s. 30.

3 T. Famulska, Sprawiedliwość podatkowa, „Przegląd Podatkowy”1996, nr 5, s. 3-5.

4 A. Gomułowicz, Zagadnienia etyki w opodatkowaniu [w:] Ksiegga pamiątkowa ku czci Profesora E. Teglera, Wydawnictwo Kameleon, Poznań 1997, s. 85. 
kresie wynika również z faktu, że jest to termin ze sfery zagadnień ogólnych prawa podatkowego, których wyraźne zdefiniowanie stwarza najwięcej problemów praktycznych ${ }^{5}$. Zwraca się także uwagę na instrumentalne wykorzystywanie kategorii sprawiedliwości podatkowej przy tworzeniu prawa podatkowego przez pewne grupy nacisku, działające w rzeczywistości wyłącznie we własnym interesie ${ }^{6}$. Nierzadko w regule sprawiedliwości szuka się również uzasadnienia dla konieczności nakładania podatków ${ }^{7}$.

Idea sprawiedliwości podatkowej oraz jej pochodnych w postaci reguł równości ${ }^{8}$ i powszechności ${ }^{9}$ opodatkowania może mieć zarówno aspekt obiektywny, jak i subiektywny ${ }^{10}$. Pierwszy z nich ma swoisty wymiar praktyczny, ponieważ uwzględniany jest przez organy władzy przy stanowieniu prawa. Drugi natomiast związany jest z postrzeganiem ustawowo nakładanego zobowiązania podatkowego przez samego podatnika, skutkującym jego oceną bądź to jako sprawiedliwy, bądź też jako niesprawiedliwy ${ }^{11}$. Realizując zatem koncepcję zasady sprawiedliwości, prawodawca podatkowy powinien uwzględniać spoczywające na państwie funkcje społeczne ${ }^{12}, \mathrm{w}$ tym postulat „słusznościowe-

${ }^{5}$ Zob. J. Kulicki, Przejrzystość i spójność polskiego ustawodawstwa podatkowego w ocenie respondentów badania ankietowego Biura Analiz Sejmowych, seria „Analizy BAS” nr 2 (144), 2017, s. 8, http://www.bas.sejm.gov.pl/analizy.php.

${ }^{6}$ A. Gomułowicz, Lobbistyczny aspekt tworzenia prawa podatkowego [w:] Prawo finansowe i nauka prawa finansowego na przełomie wieków, red. A. Kostecki, Zakamycze, Kraków 2000 , s. $80-81$.

7 J. Szołno-Koguc, Dylematy sprawiedliwości podatkowej - równość i powszechność opodatkowania a przywileje podatkowe, „Studia Ekonomiczne. Zeszyty Podatkowe Uniwersytetu Ekonomicznego w Katowicach" 2016, nr 294, s. 165.

8 Można przy tym wyróżnić równość rozumianą jako postulat równego traktowania przez prawo wszystkich (egalitaryzm wynikający z założenia, że wszyscy są równi) oraz równomierność, zwaną również względną (relewantną) równością, zakładającą dopuszczalność zróżnicowania sytuacji prawnej różnych podmiotów, które nie odznaczają się określoną cechą wspólną i mogącą skutkować rozłożeniem ciężaru podatkowego z uwzględnieniem zdolności płatniczej (ibidem, s. 168).

9 Powszechność rozumiana jest $\mathrm{w}$ ten sposób, że w przypadku zajścia okoliczności prawnie relewantnych, wszystkie podmioty są zobowiązane do ponoszenia ciężaru podatkowego. Powszechność może być odnoszona zarówno do całego systemu podatkowego, jak i do określonego podatku. Podatek dochodowy od osób fizycznych będzie spełniał kryterium powszechności w sytuacji, gdy wszystkie osoby fizyczne (wymiar podmiotowy powszechności) będą uiszczały podatek od wszystkich swych dochodów (wymiar przedmiotowy powszechności), [za:] J. Oniszczuk, Podatki i inne daniny w orzecznictwie Trybunału Konstytucyjnego, Wydawnictwo Konieczny i Kruszewski, Warszawa 2001.

10 Zob. T. Famulska, Sprawiedliwość, op. cit., s. 4.

11 R. Szumlakowski, Zasada sprawiedliwości podatkowej, seria „Acta Erasmiana”, t. V, Varia, red. M. Sadowski, Wydział Prawa, Administracji i Ekonomii Uniwersytetu Wrocławskiego, Wrocław 2013.

12 N. Gajl, Teorie podatkowe w świecie, Wydawnictwo Naukowe PWN, Warszawa 1992. 
go" podejścia do redystrybucji dóbr, w tym również do tych podmiotów, które osiągają niski dochód mogący podlegać opodatkowaniu.

Należy przy tym wyraźnie zaznaczyć, że sprawiedliwość podatkowa nigdy nie była podstawowym motywem kształtowania systemu podatkowego. Podatki niezależnie od etapu dziejowego spełniały przede wszystkim tę samą funkcję, tj. zapewniały środki do skutecznego wypełniania przez organizację państwową jej zadań (cel fiskalny opodatkowania) ${ }^{13}$. Zapotrzebowanie państwa na wydajny dochód podatkowy nie może jednak uzasadniać i usprawiedliwiać opodatkowania sprzecznego z etycznymi standardami sprawiedliwości $i^{14}$.

Funkcjonowanie zasady sprawiedliwości podatkowej nierozerwalnie łączy się również z tym, że korzystanie przez niektórych obywateli z przywilejów przyznanych przez ustawodawcę $\mathrm{w}$ stworzonym schemacie opodatkowania dochodów osobistych oznacza polepszenie ich sytuacji materialnej. Polepszeniu temu będzie jednak odpowiadać pogorszenie sytuacji innych osób, które zobowiązane zostaną do uiszczenia faktycznie wyższego zobowiązania (nie będą one mogły skorzystać z ulg i zwolnień z podatku $)^{15}$. Opodatkowanie dokonuje się bowiem zawsze czyimś kosztem i na czyjąś korzyśćc ${ }^{16}$. Wyraża się $\mathrm{w}$ tym postulat wyważenia różnych sfer interesów finansowych w taki sposób, aby opodatkowanie było odbierane w jak najwyższym stopniu jako sprawiedliwe dla możliwie jak najszerszego kręgu zobowiązanych.

Analizując zagadnienie sprawiedliwości podatkowej w odniesieniu do podatków bezpośrednich (w tym zwłaszcza podatku dochodowego), nie sposób nie zwrócić uwagi na fakt, że istnieją trzy zasadnicze zapatrywania w tym obszarze $^{17}$. Pierwsze z nich - o dość archaicznym kształcie - zakłada, że sprawiedliwy jest ten system, w którym każdy podatnik płaci jednakową kwotę zobowiązania, bez względu na jego indywidualną sytuację materialną. Drugie podejście - określane mianem sprawiedliwości dystrybucyjnej - opiera się na założeniu, że opodatkowanie powinno być zróżnicowane w zależności od stopnia, w jakim obywatel korzysta $\mathrm{z}$ wytworzonych bogactw ${ }^{18}$. W związku $\mathrm{z}$ tym

${ }_{13}$ R. Rybarski, Nauka skarbowości, Warszawa 1935, wydanie wznowione przez Wolters Kluwer, Warszawa 2015, s. 207 i n.

14 A. Gomułowicz, Zasada sprawiedliwości podatkowej w orzecznictwie Trybunału Konstytucyjnego. Aspekt materialny, Dom Wydawniczy ABC, Warszawa 2003.

15 J. Głuchowski, Sprawiedliwość podatkowa: założenia teoretyczne i możliwości aplikacyjne [w:] System podatkowy. Stan, kierunki reformy, wplyw na wzrost gospodarczy. Stanowisko Rady Społeczno-Gospodarczej, raport nr 36, Warszawa 1999, s. 35 i n.

16 A. Gomułowicz, Ochrona wolności i praw ekonomicznych a granice opodatkowania zasady i kontrowersje, „Ruch Prawniczy, Ekonomiczny i Socjologiczny” 2005, t. LXVII, nr 3, s. 28.

${ }_{17}$ Zob. I. Szczepańska, Opodatkowanie osób fizycznych w świetle zasady sprawiedliwości podatkowej, „Ius Novum” 2015, nr 1, s. 103.

18 [Za:] M. Bouvier, Wprowadzenie do prawa podatkowego i teorii podatku, Wydawnictwo Konieczny i Kruszewski, Warszawa 2000, s. 240 i n. 
przymiot sprawiedliwego ma wyłącznie podatek proporcjonalny, jednakże bez uwzględnienia jakichkolwiek przywilejów w postaci ulg czy zwolnień. Wreszcie trzecia koncepcja - najbardziej współczesna oraz dominująca w literaturze przedmiotu - zakłada istnienie ścisłej zależności między sprawiedliwością podatkową a sprawiedliwością społeczną. Według tej teorii - za którą niewątpliwie należy się opowiedzieć - podatek dochodowy jest również instrumentem służącym zmniejszeniu nierówności przychodów w drodze nałożenia ciężaru progresywnego, silnie zindywidualizowanego oraz uwzględniającego zdolność podatkową zobowiązanego ${ }^{19}$, co $\mathrm{w}$ konsekwencji prowadzi do rozwinięcia w ramach opodatkowania dochodów osobistych systemu ulg i zwolnień.

Zatem współczesna koncepcja sprawiedliwości podatkowej rozważana na gruncie podatków dochodowych związana jest nierozerwalnie z założeniem, zgodnie z którym należy zapewnić powszechność i równość opodatkowania wszystkich obywateli, uwzględniając przy określaniu wysokości zobowiązania konieczność zaspokojenia przez podatnika z uzyskanego dochodu, po jego opodatkowaniu, elementarnych potrzeb osobistych ${ }^{20}$. Taki sposób nakładania ciężaru podatkowego odpowiada jednocześnie idei, zgodnie z którą wszystkie podmioty, charakteryzujące się daną cechą istotną $\mathrm{w}$ równym stopniu, powinny być traktowane równo, według jednakowej miary, bez zróżnicowań dyskryminujących czy faworyzujących ${ }^{21}$.

\section{System przywilejów a konieczność zapewnienia realizacji efektywności opodatkowania - właściwe wyważenie interesu podatnika i państwa}

Aprobując powyższe poglądy, należy zatem ustalić, jak w ową koncepcję sprawiedliwości podatkowej $\mathrm{w}$ podatku dochodowym wpisuje się zagadnienie związane ze stosowaniem ulg, zwolnień, odliczeń oraz kwot wolnych i kosztów.

Próbę naukowego podejścia do tej problematyki podejmowano już w XVIII wieku. Idea sprawiedliwości podatkowej A. Smitha ${ }^{22}$ zakładała bowiem, że system prawa podatkowego musi przewidywać, iż obciążenia podatkowe nakładane na obywateli powinny być adekwatne do ich dochodów i sytuacji materialnej (reguła równomierności). Przy czym nie może w tym zakresie

19 Metoda wymiaru zobowiązania (najczęściej z tytułu podatku dochodowego), zgodnie z którą wysokość należnego podatku rośnie szybciej niż proporcjonalnie w stosunku do wielkości podstawy opodatkowania.

20 Zob. A. Majchrzycka-Guzowska, Finanse i prawo finansowe, LexisNexis, Warszawa 2011, s. 123 i n.

${ }^{21}$ Zob. wyrok TK z 28 listopada 1995 r., sygn. akt K 17/95, OTK 1995, nr 3, s. 177; wyrok TK z 20 października 1998 r., sygn. akt K 7/98, OTK 1998, nr 6, s. 505.

22 A. Smith, Badania nad natura i przyczynami bogactwa narodów, Wydawnictwo Naukowe PWN, Warszawa 2015. 
dochodzić do przekroczenia materialnych granic opodatkowania, po to aby nie doszło do naruszenia źródła podatku gwarantującego dalsze uzyskiwanie przychodu, zdobywanie dochodu i powiększanie majątku ${ }^{23}$. Naruszeniu owych granic miało przeciwdziałać między innymi stosowanie systemu ulg i zwolnień $\mathrm{z}$ podatku.

Przechodząc na grunt polskich rozwiązań ustrojowych związanych $\mathrm{z}$ nakładaniem ciężarów podatkowych, należy w pierwszej kolejności zauważyć, że w systemie podatkowym, w tym przede wszystkim przy określaniu wysokości zobowiązań podatkowych oraz zasad ich ponoszenia, w sposób najbardziej wyrazisty uzewnętrznia się kolizja interesów dwóch podmiotów, tj. państwa i podatnika. Z jednej strony państwo zgodnie z postanowieniem art. $217^{24}$ oraz art. $84^{25}$ Konstytucji RP ma niezwykle szeroką swobodę w zakresie ustawowego nakładania podatków ${ }^{26}$. Z drugiej jednak strony jest ono zobowiązane do respektowania fundamentalnych zasad sprawiedliwości społecznej (art. 2 Konstytucji ${ }^{27}$ ) oraz równości wobec prawa (art. 32 Konstytucji $\left.{ }^{28}\right)$ i wywodzonej z niej zasady równości i sprawiedliwości opodatkowania (art. 84 Konstytucji) ${ }^{29}$. Dlatego też, skoro każde opodatkowanie ze swej istoty (niejako z natury podatku) narusza w określonym zakresie sferę wolności i praw ekonomicznych (ponieważ jest ingerencją $\mathrm{w}$ sferę praw podmiotowych), musi również respektować szczególne znaczenie konstytucyjnych unormowań wyznaczających ramy tej ingerencji, w tym nienaruszalność prawnych i ekonomicznych granic opodatkowania. W literaturze wskazuje się zatem, że kształt systemu podatku dochodowego powinien uwzględniać ekonomiczne prawa jednostki, które we współczesnych demokracjach urastają do rangi norm konstytucyjnych ${ }^{30}$. Należy przy tym zauważyć, że z ustrojowego punktu widzenia zasada sprawiedliwości podatkowej nie wyczerpuje się jedynie w ustanowionych w Konstytucji RP

${ }^{23}$ O których szerzej: A. Gomułowicz, Ochrona wolności, op. cit., s. 29 i n.

${ }^{24}$ Art. 217 Konstytucji RP z 2 kwietnia 1997 r. (Dz.U. nr 78, poz. 483, ze zm.), zgodnie z którym nakładanie podatków, innych danin publicznych, określanie podmiotów, przedmiotów opodatkowania i stawek podatkowych, a także zasad przyznawania ulg i umorzeń oraz kategorii podmiotów zwolnionych od podatków następuje w drodze ustawy.

${ }^{25}$ Wprowadzający zasadę powszechności w ponoszeniu ciężarów i świadczeń publicznych, w tym podatków, a zarazem ograniczający ten obowiązek wyłącznie do tych, które są określone w ustawie.

${ }^{26}$ H. Dzwonkowski, Elementy konstrukcyjne podatku w świetle art. 217 Konstytucji, „Glosa” 1999, nr 6.

${ }^{27}$ Zgodnie z którym Rzeczpospolita Polska jest demokratycznym państwem prawnym, urzeczywistniającym zasady sprawiedliwości społecznej.

28 Stanowiącym o tym, że wszyscy są wobec prawa równi oraz, że wszyscy mają prawo do równego traktowania przez władze publiczne.

${ }_{29}$ Zob. wyrok TK z 18 listopada 2014 r., sygn. akt K 23/12, OTK-A ZU 2014, nr 10, poz. 113.

30 A. Gomułowicz, Podatki a etyka, Lex Wolters Kluwer Bussines, 2013, el. 
regułach równości i powszechności opodatkowania, pełni ona bowiem również samodzielną rolę w ocenie konstytucyjności obowiązków daninowych ${ }^{31}$.

Dlatego choć państwo w związku z zasadą władztwa podatkowego ma uprawnienie do swobodnego kształtowania dochodów budżetowych oraz zapewnienia równowagi budżetowej finansów publicznych na podstawie techniki konstrukcyjnej podatków ${ }^{32}$, to jednak zawsze musi się to odbywać w granicach zakreślonych przez funkcjonowanie zasady sprawiedliwości podatkowej. W rezultacie, zachowanie właściwych proporcji między interesem państwa a interesem podatnika ${ }^{33}$, jako podstawowe założenie racjonalnej polityki podatkowej oraz pragmatycznego podejścia do ustawodawstwa podatkowego, powinno skutkować respektowaniem reguły sprawiedliwości ${ }^{34}$. Należy przy tym zwrócić uwagę, że praktycznie każda z konstytucji państw demokratycznych akcentuje zasady równości i sprawiedliwości ${ }^{35}$.

W związku z powyższym ustawodawca, regulując daną daninę podatkową zgodnie ze szczegółowymi postanowieniami ustawy podatkowej, powinien dążyć do doprecyzowania w sposób kompletny oraz jednoznaczny podstawowych elementów konstrukcyjnych podatków. Dotyczy to oczywiście także zakresu ulg i zwolnien ${ }^{36}$, aby zrealizować zasadę sprawiedliwości podatkowej ${ }^{37}$, która nie różnicowałaby sytuacji prawnopodatkowej obywateli znajdujących się w takiej samej sytuacji faktycznej ${ }^{38}$. Jednocześnie rozłożenie ciężaru podatkowego na poszczególne podmioty powinno być dokonywane $\mathrm{w}$ taki sposób, aby zostały wzięte pod uwagę ich indywidualne możliwości finansowe,

${ }^{31}$ K. Działocha, Uwagi do art. 84 Konstytucji [w:] Konstytucja Rzeczypospolitej Polskiej. Komentarz, t. III, red. L. Garlicki, Wydawnictwo Sejmowe, Warszawa 2003, s. 8.

${ }_{32}$ Zob. wyrok TK z 24 maja 1994 r., sygn. akt K 1/94, OTK 1994, nr 1.

${ }_{33}$ Trafnie określił ten swoisty dylemat A. Gomułowicz, uznając, że polityka podatkowa: winna zatem dwóm panom naraz służyć [w:] Zasada sprawiedliwości w polskim systemie podatkowym, „Ruch Prawniczy, Ekonomiczny i Socjologiczny” 1989, t. LI, nr 3.

${ }^{34}$ E. Tegler, Wybrane aspekty teoretyczne i praktyczne sprawiedliwości podatkowej [w:] Ksiega jubileuszowa prof. dr Leona Kurowskiego. Podstawowe zagadnienia prawa finansowego i polityki finansowej w Polsce w latach 1989-1997, red. E. Chojna-Duch, W. Gronowski, Wydawnictwo Konieczny i Kruszewski, Warszawa 1998, s. 53 i n.

35 [Za:] J. Kulicki, Obecny i pożądany zakres i treść konstytucyjnej regulacji zasady władztwa podatkowego państwa w Konstytucji RP z 1997 r. [w:] Dylematy reformy systemu podatkowego w Polsce, red. H. Dzwonkowski, J. Kulicki, Wydawnictwo Sejmowe, Warszawa 2016, s. 19.

${ }^{36}$ Jak wskazuje TK w wyroku 28 października 2015 r., sygn. akt K 21/14 (http://trybunal.gov.pl/s/k-2114), wyliczenie $\mathrm{z}$ art. 217 należy rozumieć jako przejaw reguły o bardziej ogólnym charakterze, zgodnie z którą wszystkie istotne elementy stosunku daninowego powinny być uregulowane bezpośrednio w ustawie.

37 Zob. wyrok TK z 9 listopada 1999 r., sygn. akt K 28/98, OTK 1999, nr 7, poz. 162.

${ }_{38}$ Zob. P. Borszowski, Pojęcie i elementy zobowiązania podatkowego [w:] Prawo finansowe, red. R. Mastalski, E. Fojcik-Mastalska, Wolters Kluwer, Warszawa 2013, s. 187 i n. 
co oznacza między innymi, że to, co jest na gruncie prawa nierówne, winno być nierówno opodatkowane ${ }^{39}$. Warto wreszcie wskazać, że wszelkie regulacje powinny służyć realizacji polityki państwa, zarówno gospodarczej, jak i społecznej, dla których „wytyczne” programowe wynikają ze szczególnych postanowień ustawy zasadniczej (np. jej art. 5, 6, 11, 18, 19, 35, 48 i 71) ${ }^{40}$.

\section{Przywileje podatkowe jako instrument realizacji celów prawodawcy}

Wyznaczenie zakresu pojęcia „sprawiedliwość podatkowa” oraz jego pochodnych w postaci reguł równości i powszechności opodatkowania implikuje konieczność dokonania w dalszej kolejności analizy pojęć „ulg, zwolnień, odliczeń oraz kwot wolnych i kosztów podatkowych”. Pozwoli to na udzielenie przekonującej odpowiedzi na pytanie, czy przyjęte regulacje prawne dotyczące opodatkowania podatkiem dochodowym w sposób właściwy i skuteczny przyczyniają się do realizacji szeroko pojmowanej zasady sprawiedliwości podatkowej.

Przystępując do eksplikacji pojęcia „ulga podatkowa”, warto zwrócić uwagę na fakt, że w świetle polskiego prawa podatkowego - w przeciwieństwie do systemów prawa innych państw ${ }^{41}$ - wyróżnia się ulgi i zwolnienia podatkowe. Przyjmuje się w tym zakresie, że najistotniejsza różnica między ulgą a zwolnieniem sprowadza się do tego, iż zastosowanie ulgi prowadzi do częściowego zaspokojenia interesu fiskalnego statio fisci, które połączone jest z jednoczesnym zmniejszeniem rozmiarów ciężaru podatkowego nakładanego na podatnika, natomiast w przypadku zwolnienia prawodawca całkowicie rezygnuje z opodatkowania, co skutkuje brakiem zaspokojenia interesu właściwego podmiotu publicznoprawnego ${ }^{42}$. Należy również wskazać, że sam termin „zwolnienie" ma na gruncie podatku dochodowego charakter normatywny, bowiem ustawodawca posługuje się nim w treści ustawy podatkowej, wykorzystując sformułowania takie jak: „wolne od podatku są"43, „zwalnia się od podatku” (art. 52 u.p.d.f.) oraz „zwolnienie nie ma zastosowania” (art. 21 ust. 1 pkt 68a u.p.d.f.). Powyższe wyodrębnienie ulgi i zwolnienia ma charakter utrwalony,

39 A. Partyka, Ekonomiczne i społeczne aspekty opodatkowania [w:] Finanse publiczne i prawo finansowe, red. A. Nowak-Far, C.H. Beck, Warszawa 2017.

40 J. Kulicki, Obecny i pożądany zakres, op. cit., s. 23.

${ }^{41} \mathrm{Na}$ przykład w brytyjskim systemie prawnym funkcjonuje jednolite pojęcie Tax Allowances, obejmujące swym zakresem zarówno ulgi, jak i zwolnienia, www.gov.uk/topic/ personal-tax/income-tax.

42 W. Nykiel, Ulgi i zwolnienia w konstrukcji prawnej podatku, Dom Wydawniczy ABC Warszawa 2002, s. 76 i n.

${ }^{43}$ Artykuł 21 ust. 1 zdanie pierwsze ustawy z 26 lipca 1991 r. o podatku dochodowym od osób fizycznych, t.j. Dz.U. 2018, poz. 200, ze zm.; dalej: u.p.d.f. 
choć z normatywnego punktu widzenia ustawodawca nakazuje utożsamiać obie instytucje ${ }^{44}$.

Ulgi i zwolnienia stanowią jeden z elementów konstrukcji prawnej podat$\mathrm{ku}^{45}$, przy czym mają one charakter niesamoistny ( $\mathrm{w}$ tym znaczeniu, że towarzyszą one regulacjom przewidującym opodatkowanie) oraz fakultatywny (co oznacza, że poszczególne konstrukcje podatku mogą nie przewidywać ulg i zwolnień), a także ogólny (nie mogą mieć zastosowania do imiennie określonych osób oraz indywidualnych zdarzeń, lecz obejmują zawsze pewne kategorie podmiotów bądź przedmiotów opodatkowania) ${ }^{46}$.

Szczególną formę zwolnień podatkowych stanowią kwoty wolne od podatku, a ściślej sumy dochodu wolnego od podatku. Są nimi normatywnie określone kwoty osiągniętego dochodu, których nieprzekroczenie nie powoduje powstania obowiązku uiszczenia zobowiązania podatkowego ${ }^{47}$.

Od zwolnienia z podatku należy odróżnić wyłączenia od opodatkowania, stanowiące swoisty wyraz desinteressement państwa co do obejmowania zakresem podmiotowym lub przedmiotowym pewnych kategorii zdarzeń. Wyłączenie od opodatkowania polega zatem na tym, że określony podmiot, znajdujący się w potencjalnym polu działania danej ustawy podatkowej, w ogóle nie uzyskuje statusu podatnika uregulowanego w niej podatku z uwagi na uzasadniony (najczęściej aksjologicznie) brak zainteresowania ustawodawcy opodatkowaniem pewnych sfer życia społecznego ${ }^{48}$.

Na zakończenie dotychczasowych rozważań, warto poświęcić kilka słów na omówienie ostatniej kategorii składającej się na system przywilejów podatkowych, która związana jest bezpośrednio z kosztami podatkowymi. Koszty podatkowe to szczególne kategorie wydatków poniesione przez określony podmiot stosunku prawnopodatkowego w celu osiągnięcia przychodów. Ich wysokość wpływa bezpośrednio na podstawę opodatkowania, wobec czego odgrywają one bardzo istotną rolę kształtującą wysokość ostatecznego poziomu obciążenia podatkiem ${ }^{49}$. W systemie opodatkowania podatkiem dochodowym

${ }^{44}$ Artykuł 3 pkt 6 ustawy z 29 sierpnia 1997 r. - Ordynacja podatkowa, t.j. Dz.U. 2015, poz. 613 ze zm.

${ }^{45}$ M. Durczyńska, Zakres ulg w polskim systemie podatkowym [w:] Dylematy reformy systemu podatkowego w Polsce, red. H. Dzwonkowski, J. Kulicki, Wydawnictwo Sejmowe, Warszawa 2016, s. 437.

46 A. Krzywoń, Podatki i inne daniny publiczne w Konstytucji Rzeczypospolitej Polskiej, Wydawnictwo Sejmowe, Warszawa 2011, s. 68.

47 Zob. H. Dzwonkowski, J. Gliniecka, Prawo finansowe, C.H. Beck, Warszawa 2013, s. 234.

48 Zob. m.in. art. 2 ust. 1 pkt 4 u.p.d.f. przewidujący, że przepisów ustawy nie stosuje się do przychodów wynikających z czynności, które nie mogą być przedmiotem prawnie skutecznej umowy.

49 A. Gomułowicz, Koszty uzyskania przychodów. Zasady ogólne, „Przegląd Podatkowy” 2006, nr 5. 
niektóre kategorie kosztów podatkowych zostały ze względów pragmatycznych (łatwość obliczenia oraz poboru podatku) określone w sposób zryczałtowany. Ich normatywnie wyrażona wysokość bądź to nie ma jakiegokolwiek bezpośredniego związku z faktyczną wysokością uzyskanego przez podatnika przychodu oraz wielkością poniesionych kosztów ${ }^{50}$, bądź też opiera się na tzw. normatywie kosztów w przychodzie, w ramach którego koszt podatkowy stanowi określony procent przychodu ${ }^{51}$.

Tak jak wyżej wskazano, zasadniczą funkcją podatków jest realizacja celu fiskalnego, polegającego na gromadzeniu środków publicznych. Wyjątkowy charakter prawny podatku dochodowego umożliwia jednak również wypełnianie w szerokim zakresie celów pozafiskalnych, w tym o charakterze społecznym lub gospodarczym ${ }^{52}$. Wśród zasadniczych funkcji realizowanych przez zwolnienia i ulgi na gruncie podatku dochodowego wyróżnia się ${ }^{53}$ :

- wzmocnienie sytuacji materialnej określonej grupy podatników ${ }^{54}$,

- docenienie osób o określonych zasługach dla państwa lub społeczności lokalnej ${ }^{55}$,

- stymulowanie określonych sfer życia publicznego ${ }^{56}$.

Biorąc pod uwagę powyższe, należy dojść do wniosku, że choć funkcjonowanie systemu ulg i zwolnień podatkowych $\mathrm{w}$ zakresie podatku dochodowego pozostaje w oczywistej sprzeczności z możliwością natychmiastowej realizacji celu fiskalnego, to jednak bądź to spełnia ważne społeczne potrzeby ${ }^{57}$, bądź też może w dłuższej perspektywie w drodze modyfikacji działań podatników doprowadzić do powiększenia strumienia wpływów podatkowych przez rozwój określonych sektorów gospodarki ${ }^{58}$.

${ }^{50}$ Zob. np. art. 22 ust. 2 u.p.d.f., dotyczący tzw. zryczałtowanych kosztów pracowniczych.

${ }^{51} \mathrm{Na}$ przykład art. 22 ust. 9 pkt 4 u.p.d.f., związany z większością przychodów uzyskanych z działalności wykonywanej osobiście.

${ }_{52}$ Zob. wyrok TK z 29 lipca 2014 r., sygn. akt P 49/13, OTK-A ZU nr 7, poz. 79, i cytowane tam orzecznictwo; wyrok TK z 12 kwietnia 2011 r., sygn. akt SK 62/08, OTK-A ZU 2011, nr 3, poz. 22.

${ }_{53}$ Zob. W. Nykiel, Cele i funkcje ulg i zwolnień podatkowych [w:] Regulacje prawno-podatkowe i rozwiąania finansowe. Pro publico bono. Ksiega jubileuszowa Profesora Jana Głuchowskiego, TNOiK, Toruń 2002.

${ }^{54} \mathrm{Na}$ przykład art. 21 ust. 1 pkt 127 u.p.d.f., przewidujący zwolnienie z podatku otrzymanych alimentów.

${ }^{55} \mathrm{Na}$ przykład zwolnienie rent wypłaconych osobom represjonowanym i członkom ich rodzin na podstawie art. 21 ust. 1 pkt 75 u.p.d.f.

${ }^{56} \mathrm{Na}$ przykład zwolnienie stypendiów otrzymanych na podstawie przepisów o stopniach naukowych i tytule naukowym, art. 21 ust. 1 pkt 39 u.p.d.f.

57 Na przykład art. 21 ust. 1 pkt 26 u.p.d.f. przewidujący zwolnienia z podatku zapomóg otrzymanych w przypadku indywidualnych zdarzeń losowych.

${ }^{58}$ Na przykład ulga na działalność badawczo-rozwojową uregulowana w art. 26e u.p.d.f. 


\section{Ulga i zwolnienie - wyłom od zasady czy też skuteczna realizacja reguły sprawiedliwości?}

Mając na uwadze powyższe założenia, należy rozwinąć kwestię dotyczącą tego, w jaki sposób system ulg i zwolnień w podatku dochodowym wpisuje się w konstytucyjne zasady sprawiedliwości, równości i powszechności opodatkowania. W tym celu trzeba zbadać charakter prawny przywilejów (w tym przede wszystkim ulg i zwolnień) oraz ich obecny kształt w świetle systemu uprawnień wynikających $\mathrm{z}$ funkcjonowania szeroko pojmowanej zasady sprawiedliwości podatkowej.

Warto już w tym miejscu zauważyć, że istnieje stanowisko, zgodnie z którym wszelkie przywileje funkcjonujące na gruncie podatku dochodowego, jako naruszające wprost reguły powszechności i równości, powinny być wyeliminowane $\mathrm{z}$ systemu podatkowego ${ }^{59}$. Z powyższym zapatrywaniem nie sposób się jednak zgodzić. Należy sformułować twierdzenie zgoła odmienne, przewidujące, że omawiane przywileje stanowią właśnie narzędzie służące realizacji zasady sprawiedliwości podatkowej, nie naruszające przy tym zasady powszechności opodatkowania. Są one wyrazem specyficznego podejścia prawodawcy do podatnika, które to podejście mieści się jednak w ogólnej regule opodatkowania. Pewne odmienne traktowanie wynikające z zastosowania ulgi lub zwolnienia jest w pełni usprawiedliwione, bowiem zróżnicowane są także sytuacje i okoliczności, w jakich znajdują się poszczególne grupy podmiotów ${ }^{60}$.

Trzeba przy tym kategorycznie zastrzec, że funkcjonowanie w systemie podatku dochodowego ulg i zwolnień, które mają spełniać wymogi sprawiedliwości podatkowej, nie może być poddane całkowitej dowolności. Należy w tym względzie respektować również inne wartości konstytucyjnie chronione, takie jak:

- spoczywający na państwie obowiązek realizacji określonych celów społecznych finansowanych z podatku (np. art. 68 Konstytucji dotyczący ochrony zdrowia),

- reguły dotyczące wolności działalności gospodarczej i równego traktowania przedsiębiorców (art. 22 Konstytucji), czy też wreszcie

- zasady ochrony własności (art. 21 oraz art. 64 Konstytucji), przejawiające się również w tym, że nie można dopuścić do sytuacji, w której zbyt szerokie i niedostatecznie uzasadnione stosowanie przywilejów podatkowych wobec określonych podmiotów może stworzyć w pozostałej grupie podatników usprawiedliwione przekonanie, że spotkała

59 T. Hałajasz, Przestrzeganie zasad podatkowych w konstrukcji podatków dochodowych [w:] Finanse publiczne $w$ warunkach przekształceń $w$ gospodarce, red. J. Sokołowski, Wydawnictwo Akademii Ekonomicznej, Wrocław 1996, s. 58.

${ }^{60}$ Zob. A. Leszczyńska, Ulgi i zwolnienia podatkowe w świetle zasady sprawiedliwości podatkowej, „Kwartalnik Prawa Podatkowego” 2006, nr 2, s. 37 i n. 
ich niesprawiedliwość i czują się dyskryminowani (przez nadmierne uszczuplenie ich majątku); taka sytuacja mogłaby prowadzić do utraty zaufania do systemu podatkowego jako całości oraz ostatecznie również do samego państwa.

W orzecznictwie Trybunału Konstytucyjnego (TK) odnoszącym się w szczególności do ulg i zwolnień podatkowych funkcjonujących na gruncie podatku dochodowego dosyć powszechnie ${ }^{61}$ wyrażane jest stanowisko, zgodnie z którym prawo do zwolnienia czy ulgi podatkowej na gruncie podatku dochodowego nie stanowi prawa konstytucyjnego o charakterze podmiotowym, bowiem zwolnienia i ulgi to odstępstwo od zasady powszechności opodatkowania i równości opodatkowania, mają zatem charakter wyjątkowy, a o ich wprowadzeniu i zakresie decyduje swobodnie ustawodawca. Przyjmuje się przy tym, że samo wprowadzenie przez prawodawcę zwolnienia podatkowego nie jest zasadniczo jednoznaczne z powstaniem prawa do osiągania dochodów w sposób niepodlegający opodatkowaniu, swoistego „prawa do zwolnienia podatkowego", skoro zgodnie z art. 84 Konstytucji każdy jest obowiązany do ponoszenia ciężarów i świadczeń publicznych, w tym podatków określonych w ustawie. Z tych względów - w niektórych ocenach Trybunału - niezasadne jest traktowanie prawa do zwolnienia podatkowego jako prawa słusznie (niewadliwie) nabytego, którego ochronę gwarantuje zasada demokratycznego państwa prawnego ${ }^{62}$.

Jeszcze dalej w kwestionowaniu ulg i zwolnień jako elementów stanowiących urzeczywistnienie zasady sprawiedliwości podatkowej idzie nierzadko w swym orzecznictwie Naczelny Sąd Administracyjny (NSA), który stoi na stanowisku, że istnieje nawet swoista kolizja pomiędzy systemem ulg i zwolnień a zasadą sprawiedliwości: wszelkie zwolnienia i ulgi podatkowe w systemie prawa polskiego sq wyjątkiem, istotnym odstępstwem od zasady sprawiedliwości podatkowej (powszechności i równości opodatkowania) ${ }^{63}$.

Powyższe zapatrywanie sądów i Trybunału nie zasługuje jednak w mojej ocenie na uwzględnienie i to $\mathrm{z}$ kilku zasadniczych powodów.

${ }^{61}$ Zob. m.in. wyroki TK z: 17 listopada 2009 r., sygn. akt SK 64/08, OTK-A ZU 2009, nr 10, poz. 148; 25 kwietnia 2001 r., sygn. akt K 13/01, OTK ZU 2001, nr 4, poz. 81; 7 czerwca 1999 r., sygn. akt K 18/98, OTK 1999, nr 5, poz. 95; 29 maja 1996 r., sygn. akt K 22/95, OTK 1996, nr 3, poz. 21.

${ }_{62}$ Zob. wyrok TK z 27 lutego 2002 r., sygn. akt K 47/01, OTK-A ZU 2002, nr 1, poz. 6, a także postanowienia TK: z 22 lipca 2014 r., sygn. akt Ts 230/13, oraz z 14 lipca 2004 r., Ts 21/04, OTK-B ZU 2005, nr 1, poz. 19.

${ }_{63}$ Zob. wyroki NSA: z 4 października 2016 r., sygn. akt I FSK 878/14; z 7 kwietnia 2016 r., sygn. akt I FSK 1963/14; z 29 lipca 2005 r., sygn. akt I FSK 77/05; z 16 września 2015 r., sygn. akt I GSK 100/14; z 27 października 2011 r., sygn. akt akt II FSK 753/10, Centralna Baza Orzeczeń Sądów Administracyjnych, http://orzeczenia.nsa.gov.pl. 
Po pierwsze, nie bierze pod uwagę tego, że zasada sprawiedliwości zakłada - o czym wspominano wyżej - nie tylko to, że wszyscy mają obowiązek łożyć na pokrywanie wspólnych potrzeb w zakresie określonym przez ustawę podatkową, ale również i to, że musi to nastąpić przy uwzględnieniu właściwej miary opodatkowania, tak aby rozkład ciężarów podatkowych był uzależniony od zdolności gospodarczych podatnika ${ }^{64}$. W rezultacie nie ulega wątpliwości, że system ulg i zwolnień, który uwzględnia ową zależność, „mieści się” w regule sprawiedliwego opodatkowania.

Po drugie, o konieczności wprowadzania w podatku dochodowym rozwiązań prawnych w zakresie ulg i zwolnień nie decydują - jak wyżej wskazywano - przesłanki o charakterze prawnym, ale przede wszystkim zasadnicze uwarunkowania społeczno-ekonomiczne. Ich źródeł należy szukać w regule sprawiedliwości prawa, która z kolei stanowi fundament zasady sprawiedliwości podatkowej. Zatem nie może być mowy o jakimkolwiek konflikcie między systemem ulg i zwolnień a zasadą sprawiedliwości podatkowej, w której upatrują one rację swego bytu.

Po trzecie, system ulg i zwolnień nie prowadzi do naruszenia zasad powszechności i sprawiedliwości opodatkowania, a jedynie „modeluje” racjonalny zakres przedmiotu i podmiotu opodatkowania (wyrównując częstokroć warunki podmiotom znajdującym się w specyficznych sytuacjach), co powoduje, że w rzeczywistości explicite realizowana jest zasada równości podatkowej. Nie można przy tym tracić $\mathrm{z}$ pola widzenia tego, że również $\mathrm{w}$ orzecznictwie wskazuje się, iż podatki nie powinny być większym ciężarem niż jest to absolutnie konieczne, a obowiązek płacenia podatków nie może prowadzić do ubóstwa obywateli (podatników) ${ }^{65}$.

Po czwarte, stanowisko mówiące o tym, że ulgi stanowią odstępstwo od zasady sprawiedliwości, nie może się obronić, bowiem jeśli przyjmiemy, że na gruncie opodatkowania osób fizycznych zasadniczą miarę opodatkowania miałby stanowić sam osiągnięty dochód (jego wielkość), to jednocześnie często mielibyśmy do czynienia z sytuacją, gdy osoby o takiej samej wielkości dochodu poprzez taki sam zakres opodatkowania objęte byłyby takim samym zobowiązaniem, wówczas w konsekwencji traktowane byłyby w oczywisty sposób nierówno i niesprawiedliwie ${ }^{66}$. Zatem stosowanie tzw. ulgi wyrównawczej, mającej swe korzenie w aksjologii polityki podatkowej, nie tylko nie godzi w zasadę równości, ale wręcz zapewnia jej skuteczną realizację.

${ }^{64}$ R. Mastalski, Prawo podatkowe, C.H. Beck, Warszawa 2016.

${ }_{65}$ Zob. wyrok TK z 28 października 2015 r., sygn. akt K 21/14, http://trybunal.gov. $\mathrm{pl} / \mathrm{s} / \mathrm{k}-2114$.

${ }^{66}$ Na przykład osoba pozostająca w bezdzietnym związku małżeńskim, w którym oboje małżonkowie osiągają dochód versus osoba samotna wychowująca kilkoro małoletnich dzieci. 
Po piąte, jeśli podmiot zobowiązany nie jest w stanie wypełnić obowiązku podatkowego, wówczas maleją korzyści (zarówno w sferze finansów publicznych, jak i w sferze społecznej) wynikające $\mathrm{z}$ realizacji tego obowiązku. Toteż uwzględnienie rzeczywistej możliwości poniesienia ciężaru publicznego przez podatnika, czyli zastosowanie również określonej kategorii ulgi bądź zwolnienia, powoduje, że podatek realizuje cele, dla których został ustanowiony. W przeciwnym razie, tj. jeśli podatek mógłby być określony całkowicie swobodnie, $\mathrm{z}$ pominięciem zdolności podatkowej, możliwość jego egzekwowania byłaby niekiedy iluzoryczna. Na jednostkę nakładano by ciężar, którego nie byłaby w stanie ponieść. Użyteczność podatku nałożonego na osobę bez zdolności podatkowej staje się w takim wypadku wątpliwa, co z kolei musi oznaczać, że system ulg i zwolnień w podatku dochodowym stanowić może w określonych sytuacjach wyraz realizacji prawa konstytucyjnego o charakterze podmiotowym, urzeczywistniającego zasadę sprawiedliwości podatkowej. W rezultacie, $\mathrm{z}$ uwagi na powyższe uwarunkowania, nie we wszystkich sytuacjach państwo może zatem korzystać z przysługującej mu swobody legislacyjnej w pełnym zakresie. Ograniczenia wynikające z konieczności respektowania między innymi zasady sprawiedliwości podatkowej dotyczą również systemu ulg i zwolnień w podatku dochodowym.

Po szóste wreszcie, choć przepisy Konstytucji RP nie wskazują materialnych granic opodatkowania ${ }^{67}$, to swoboda władzy ustawodawczej w stanowieniu prawa odpowiadającego celom politycznym i gospodarczym ma charakter względny. Wobec tego wprowadzone rozwiązania legislacyjne w zakresie prawa podatkowego nie mogą prowadzić do naruszenia istoty praw konstytucyjnych, więc prawo do zwolnienia czy ulgi podatkowej na gruncie podatku dochodowego, jako materializacja praw konstytucyjnych o ogólnym charakterze, samo może stanowić szczególne podmiotowe prawo konstytucyjne.

\section{Ocena szczegółowych regulacji pod kątem urzeczywistnienia zasady sprawiedliwości}

Aby dowieść tego, że funkcjonowanie określonych form przywilejów podatkowych na gruncie podatku dochodowego może stanowić konstytucyjne prawo podmiotowe, wypełniające zasadę sprawiedliwości podatkowej, należy przyjrzeć się obowiązującym w tym obszarze unormowaniom, które tworzą poszczególne kategorie ulg i zwolnień.

Trzeba też poczynić istotne zastrzeżenie, że nie sposób jest dokonać analizy wszystkich form przywilejów obowiązujących w ramach podatku docho-

67 Zob. orzeczenia TK z: 24 maja 1994 r., sygn. akt K 1/94, OTK 1994, cz. 1, poz. 10; 14 grudnia 1993 r., sygn. akt K 8/93, OTK 1993, cz. 2, poz. 43, oraz wyroki TK z: 25 listopada 1997 r., sygn. akt K 26/97, OTK 1997, nr 5-6, poz. 64; 25 kwietnia 2001 r., sygn. akt K 13/01, OTK ZU 2001, nr 4, poz. 81. 
dowego przez pryzmat zasady sprawiedliwości podatkowej. Dlatego zasadne jest skupienie się na tych rozwiązaniach, które są najczęściej wykorzystywane, wzbudzają najwięcej wątpliwości, oraz tych, w których zakresie funkcjonowania w ostatnim czasie doszło do istotnych zmian. Takie podejście uzasadnione jest tym, że umożliwia przeanalizowanie najbardziej aktualnych kierunków działań prawodawcy oraz dokonanie oceny skutków ich realizacji.

W pierwszej kolejności warto się zatrzymać przy zagadnieniu dotyczącym problemu kwoty wolnej od podatku, ponieważ w związku z powoływanym już wyżej wyrokiem Trybunału Konstytucyjnego w sprawie o sygn. akt K 21/14 ustawodawca został zobowiązany do wprowadzenia istotnych zmian $\mathrm{w}$ tym zakresie $^{68}$. Trybunał uznał, że brak mechanizmu korygującego kwotę zmniejszającą podatek dochodowy od osób fizycznych, a zatem wieloletnie utrzymywanie kwoty wolnej od podatku na stałym poziomie i uniezależnienie jej od sytuacji społeczno-gospodarczej państwa i podatnika, jest wadliwością prawa podatkowego niedopuszczalną $\mathrm{w}$ świetle zasady sprawiedliwości podatkowej, wywodzonej między innymi z konstytucyjnej zasady demokratycznego państwa prawnego. Stąd brak powiązania zdolności podatkowej z przepisami odnoszącymi się do minimum egzystencji lub innymi określonymi wskaźnikami społeczno-ekonomicznymi powoduje, że obowiązujące w tym względzie przepisy - choć poprawne pod względem formalnym - stają się niesprawiedliwe.

W związku z powyższym uznać należy, że wdrażane przez prawodawcę w ciągu ostatnich dwóch lat zmiany w zakresie określenia wysokości kwoty wolnej od podatku zasługują na pełną aprobatę. Wprowadzane od początku 2017 r. regulacje przewidują, że realnie podatku dochodowego nie muszą uiszczać osoby uzyskujące wyjątkowo niskie dochody, klasyfikujące je jako podmioty żyjące w ubóstwie ${ }^{69}$. Co więcej, z początkiem 2018 r. wprowadzono kolejną modyfikację unormowań zmierzającą do rozszerzenia kręgu podmiotów, u których niewielka wysokość podstawy obliczenia podatku nie powoduje powstania obowiązku zapłaty podatku ${ }^{70}$, co skutkuje w praktyce tym, że zwol-

${ }^{68}$ Art. 27 u.p.d.f. w ocenianym przez Trybunał Konstytucyjny stanie prawnym przewidywał kwotę wolną od podatku na poziomie 3091 zł rocznie.

${ }^{69}$ Art. 27 ust. 1a dodany przez art. 1 pkt 2 lit. b ustawy z 29 listopada 2016 r. (Dz.U. poz. 1926) zmieniającej ustawę o podatku dochodowym od osób fizycznych z dniem 1 stycznia 2017 r. przewiduje całkowite zwolnienie dla podstawy obliczenia podatku nieprzekraczającej 6600 zł i częściowe zwolnienie osób, u których podstawa obliczenia podatku nie przekracza $11000 \mathrm{zł}$.

70 Art. 1 pkt 17 ustawy z 27 października 2017 r. (Dz.U. poz. 2175; dalej: ustawa z 27 października 2017 r.) zmieniającej ustawę o podatku dochodowym od osób fizycznych z dniem 1 stycznia 2018 r. przewiduje, że zobowiązania nie uiszczają osoby, u których wartość podstawy obliczenia podatku nie przekracza 8000 zł, natomiast częściowo zwolnione są osoby z podstawą obliczenia podatku nieprzewyższającą $13000 \mathrm{zł.}$ 
nione $\mathrm{z}$ obowiązku ponoszenia ciężaru są osoby uprawnione do świadczeń pieniężnych z pomocy społecznej.

Przedstawione działania legislacyjne wskazują, że często sam prawodawca (choć nie zawsze $z$ własnej inicjatywy) dokonuje słusznej i pożądanej zmiany przepisów, nieodpowiadających standardom sprawiedliwości podatkowej, w sytuacji gdy przyczyna ich wadliwości tkwi właśnie w ich niezgodności z ową zasadą. Potwierdza to po raz kolejny formułowane wyżej stanowisko mówiące o tym, że stosowanie przywilejów, takich jak na przykład kwota wolna od podatku, nie stanowi wyłomu od realizacji zasady sprawiedliwości podatkowej, lecz może ją tylko wspierać i w konsekwencji uzasadniać zmianę niepożądanych unormowań.

W kontekście analizowanego zagadnienia warto zauważyć, że nie zawsze jednak ustawodawca staje na wysokości zadania w obszarze urzeczywistnienia reguły równości i sprawiedliwości. Uzasadniając powyższe, należy skierować uwagę na unormowania dotyczące kosztów uzyskania przychodów z tytułu dochodów uzyskiwanych przez osoby fizyczne nieprowadzące działalności gospodarczej, w szczególności z uwzględnieniem tzw. kosztów pracowniczych (art. 22 ust. 2 u.p.d.f.). Skonstatować trzeba, że przepisy funkcjonujące obecnie w tym zakresie nie spełniają wymogów sprawiedliwości opodatkowania, zwłaszcza jeśli zestawi się je z unormowaniami stosowanymi wobec osób uzyskujących dochody z tytułu niektórych kategorii działalności wykonywanych osobiście (art. 22 ust. 9 pkt 4 u.p.d.f.) oraz wobec twórców i artystów wykonawców (art. 22 ust. 9 pkt 3 u.p.d.f.).

Aby dowieść powyższych zastrzeżeń, w pierwszej kolejności warto zauważyć, iż normatywnie wyrażona wysokość kosztów pracowniczych ${ }^{71}$ nie ma jakiegokolwiek bezpośredniego związku zarówno z faktyczną wysokością uzyskanego przychodu, jak i wielkością faktycznie poniesionych wydatków i, co najistotniejsze, pozostaje na niezmienionym poziomie od ponad 11 lat $^{72}$. W związku z tym, o ile w roku 2007 wysokość zasadniczych miesięcznych kosztów „pracowniczych" stanowiła ok. 4,5\% średniego miesięcznego wynagrodzenia $^{73}$, o tyle w roku 2018 stanowi zaledwie jego 2,2\%. Analogiczne relacje zachodzą w przypadku uwzględnienia stosunku kosztów do płacy minimal-

${ }^{71}$ Zasadniczo w wysokości 111 zł 25 gr miesięcznie (art. 22 ust. 2 pkt 1 u.p.d.f.).

72 Ostatnia nowelizacja przewidująca podwyższenie kosztów pracowniczych miała miejsce na podstawie ustawy z 16 listopada 2006 r. (Dz.U. nr 217, poz. 1588), która weszła w życie od 1 stycznia $2007 \mathrm{r}$.

73 Wynagrodzenie $\mathrm{w}$ gospodarce narodowej $\mathrm{w}$ poprzednim roku kalendarzowym, ogłaszane corocznie przez Prezesa Głównego Urzędu Statystycznego, w formie komunikatu, w Dzienniku Urzędowym Rzeczypospolitej Polskiej „Monitor Polski”, http://www. zus.pl/baza-wiedzy/skladki-wskazniki-odsetki/wskazniki/przecietne-wynagrodzenie-w-latach-1950-2014 [dostęp: 14 lutego 2018 r.]. 
nej $\left(12,4 \%\right.$ w roku 2007 oraz 5,2\% w roku $\left.2018^{74}\right)$. Jak zatem łatwo zauważyć, w ciągu ostatnich lat nastąpiło de facto zasadnicze obniżenie wielkości kosztów uzyskania przychodów, które mogą być uwzględnione przez podatników pozostających w stosunku pracy. Fakt ów nie niósłby za sobą istotnych konsekwencji na gruncie analizy unormowań pod kątem funkcjonowania zasady sprawiedliwości podatkowej, gdyby nie to, że w odniesieniu do innych niż pracownicza form wykonywania pracy (w tym pracy twórczej) realna wielkość możliwych do uwzględnienia kosztów podatkowych jest nie dość że dużo wyższa, to dodatkowo uwzględnia proporcję zachodzącą między wzrostem wynagrodzenia a wielkością możliwych do uwzględnienia kosztów. I tak przykładowo w odniesieniu do osób wykonujących pracę bądź świadczących usługi na podstawie umowy-zlecenia lub umowy o dzieło koszty uzyskania przychodów określa się na poziomie $20 \%$ uzyskanego przychodu (art. 22 ust. 9 pkt 4 w związku z art. 13 pkt 8 u.p.d.f.). Oznacza to, że osoba osiągająca $z$ tego tytułu miesięczne wynagrodzenie np. na poziomie średniego wynagrodzenia „pracowniczego" może uwzględnić jako koszt uzyskania przychodu sumę aż dziewięciokrotnie wyższą niż „zwykły pracownik” (tj. 995 zł). Co więcej, w ostatnich jedenastu latach, kiedy to koszty pracownicze w omawianej sytuacji pozostawały na niezmienionym poziomie, $w$ odniesieniu do takiego samego dochodu osiągniętego $\mathrm{z}$ tytułu umów cywilnoprawnych uległy ponaddwukrotnemu wzrostowi. Wszystko to prowadzi do jednoznacznego wniosku, że obecnie funkcjonujące regulacje dotyczące uwzględniania kosztów podatkowych w przypadku pracowniczych form zatrudnienia nie realizują zasady sprawiedliwości i równości opodatkowania. Niespełnianie przez wskazane normy zasad sprawiedliwości staje się jeszcze bardziej wyraziste, kiedy weźmie się pod uwagę zasady uwzględniania kosztów wobec grupy obejmującej twórców i artystów wykonawców, przewidujące stosowanie aż 50\% kosztów uzyskania przychodów (art. 22 ust. 9 pkt 3 u.p.d.f.). $\mathrm{W}$ takiej sytuacji osoba korzystająca $\mathrm{z}$ owej preferencji w porównaniu $\mathrm{z}$ „typowym” pracownikiem, przy założeniu identycznej kwoty miesięcznego przychodu w wysokości przeciętnego wynagrodzenia może zaliczyć w poczet kosztów podatkowych sumę aż 22-krotnie wyższą (2486 zł wobec ok. 111 zł), co bez wątpienia powinno pobudzić do głębokiej refleksji nad obecnym systemem uwzględniania kosztów pracowniczych, ocenianych z punktu widzenia reguł sprawiedliwości podatkowej.

Pragnę przy tym podkreślić, że reguła sprawiedliwości czy też równości opodatkowania nie sprzeciwia się stosowaniu przywilejów wobec twórców i wykonawców dysponujących częstokroć specjalistyczną wiedzą i wykształceniem, których samo zdobycie jak i aktualizacja wiążą się z istotnymi wysiłkami i nakładami. Przykłady wskazane wyżej mają jedynie unaocznić pilną potrzebę

${ }^{74} \mathrm{Http}$ ///www.zus.pl/baza-wiedzy/skladki-wskazniki-odsetki/wskazniki/minimalne-wynagrodzenie-za-prace-od-2003-r [dostęp: 14 lutego 2018 r.]. 
zmian dotyczących kosztów pracowniczych, które uległy swoistej niepożądanej petryfikacji i w żadnej mierze nie odzwierciedlają już realnych nakładów ponoszonych przez pracowników. Można nawet zaryzykować twierdzenie, że koszty te, będąc przecież jednym z podstawowych elementów konstrukcyjnych podatku dochodowego, stanowią $\mathrm{w}$ chwili obecnej de facto symboliczną instytucję fasadową.

W związku z opisanymi wyżej uwarunkowaniami pożądane zmiany systemu naliczania kosztów pracowniczych powinny zmierzać w kierunku rozwiązań analogicznych do tych, które obowiązują obecnie w umowach cywilnoprawnych (opartych na procentowym normatywie kosztów w przychodzie). Uzasadnienie dla tego rodzaju modyfikacji wynika nie tylko z tego powodu, że system powinien traktować podatników znajdujących się w zbliżonych okolicznościach w sposób równy (bądź maksymalnie wyrównany), ale również ze względu na fakt, że zaproponowany model powoduje niejako automatyczne uwzględnienie wzrostu wysokości kosztów w przypadku naturalnie występujących na przestrzeni lat podwyższeń wielkości przychodu (choćby tylko np. o wskaźnik inflacji). Uzasadniając konieczność wprowadzenia owych zmian, nie można również tracić z pola widzenia faktu, że jednymi z najistotniejszych przyczyn niekorzystnej „migracji” podatników ze stosunku pracy w kierunku tzw. samozatrudnienia (w sytuacjach, gdy charakter pracy wyraźnie i jednoznacznie wskazuje na to, że ma ona cechy stricte pracownicze), są względy fiskalne, w tym również korzystniejsza dla podatników forma rozliczania podatku w postaci uwzględnienia faktycznych kosztów uzyskania przychodów.

Analizując unormowania dotyczące przywilejów podatkowych, warto poddać jeszcze ocenie powoływane wyżej unormowania dotyczące stosowania 50\% kosztów wobec twórców i artystów wykonawców z tytułu korzystania przez nich z praw autorskich i praw pokrewnych lub rozporządzania tymi prawami. Przede wszystkim należy zauważyć, że w ostatnim czasie (art. 1 pkt 8 lit. d ustawy z 27 października 2017 r.) ustawodawca zdecydował o tym, że w samej ustawie zamieszczona zostanie lista kategorii podmiotów, wobec których zastosowanie znajdą podwyższone koszty (art. 22 ust. 9 b u.p.d.f.). Wykaz ten $\mathrm{w}$ dużej mierze opiera się na archaicznym zestawieniu wynikającym z przepisów o prawach autorskich i pokrewnych z 1994 r. i nie zawiera istotnych współcześnie występujących zajęć o niewątpliwie twórczym charakterze. Wskutek tego można słusznie zarzucać, iż kształt listy - wobec pominięcia w niej np. branży kreatywnej, IT, grafiki użytkowej, twórców gier komputerowych czy też wreszcie inżynierów budownictwa - narusza reguły równego traktowania, a tym samym również sprawiedliwości podatkowej. Dlatego też należy dojść do przekonania, że istnieje pilna potrzeba dokonania nowelizacji wskazanej regulacji, która - jeśli uwzględni się również to, iż wskutek rozwoju nowych dziedzin twórczych będzie musiała być dokonywana cyklicznie - stawia pod znakiem zapytania także samą zasadność zamieszczenia wskazanej listy zajęć 
twórczych w ustawie. Taki zabieg legislacyjny zawsze będzie bowiem przedmiotem zarzutów dotyczących pominięcia określonej nowej kategorii przejawu działalności twórczej, a tym samym naruszenia zasady równego traktowania.

Pozostając przy ocenie samej zawartości wprowadzonej przez ustawodawcę listy form aktywności $\mathrm{z}$ art. 22 ust. $9 \mathrm{~b}$ u.p.d.f. przez pryzmat zasady sprawiedliwości podatkowej, warto zauważyć, że zawiera ona również pewne kategorie działalności twórczych, które wzbudzają wątpliwości co do uznania ich za na tyle ważkie społecznie, aby objąć je preferencją podatkową. Powstaje bowiem pytanie o to, czy na przykład wykonawcy sztuki cyrkowej czy też kaskaderzy, a więc bez wątpienia przedstawiciele branż o charakterze rozrywkowym, winni być rzeczywiście objęci uprzywilejowaniem w postaci stosowania przy obliczaniu wysokości zobowiązania wielkości kosztów uzyskania przychodów wielokrotnie wyższych niż na przykład pracownicy zajmujący się ratowaniem życia i zdrowia (np. ratownicy medyczni czy pielęgniarki), uwzględniający wyłącznie koszty pracownicze. Wydaje się, że taki przywilej nie może się obronić zarówno z ogólnospołecznych względów aksjologicznych, jak i w świetle zasady równości opodatkowania. Stąd należałoby bądź to istotnie zmodyfikować (ograniczyć) kategorie działalności twórczych objętych 50\% kosztami, bądź też zrezygnować z niej w całości, opierając się przy uwzględnianiu kosztów - tak jak miało to miejsce we wcześniejszym stanie prawnym - na kryterium powstania dzieła w rozumieniu ustawy o prawie autorskim i prawach pokrewnych.

Kończąc rozważania dotyczące zmian w zakresie stosowania podwyższonych kosztów wobec działalności twórczej, warto wspomnieć o pewnej niekonsekwencji prawodawcy, która ma także bezpośredni związek z regułą sprawiedliwości podatkowej. Otóż z jednej strony motywując wprowadzenie istotnego ograniczenia w zakresie dopuszczalności uwzględniania podwyższonych kosztów, w uzasadnieniu do ustawy zmieniającej ${ }^{75}$ argumentowano, że 50\% koszty stanowią szczególne uprawnienie, wyjątek od zasady powszechności opodatkowania, a zatem bez wprowadzonego limitu ograniczającego stanowiłyby przywilej zbyt daleko idący w świetle postanowień art. 84 Konstytucji RP. Z drugiej strony, kiedy ostatnimi czasy znoszono wskazane ograniczenie funkcjonujące zaledwie od 4 lat ${ }^{76}$, względy powszechności opodatkowania nie stały na przeszkodzie wycofaniu się z dotychczasowego limitu, a uzasadnienie nowelizacji sprowadzało się jedynie do twierdzenia, że zmiany stanowią wyjście naprzeciw oczekiwaniom podatników wykonujących twórcze zawody. Powyższa okoliczność wskazuje wyraźnie nie tylko na to, że prawodawca

75 Ustawa nowelizująca z 24 października 2012 r. (Dz.U. poz. 1278, ze zm.), która przewidywała, że podwyższone koszty nie mogą mieć zastosowania do podstawy obliczania podatku przekraczającej połowę kwoty stanowiącej górną granicę pierwszego przedziału skali podatkowej.

${ }^{76}$ Chodzi o ustawę z 27 października 2017 r. 
nie ma spójnej, czytelnej, a przede wszystkim konsekwentnej wizji stosowania omawianego przywileju, ale również mówi o tym, że reguła sprawiedliwości i powszechności opodatkowania może stanowić zarówno podstawę wprowadzania określonych unormowań, jak i pozostawać w zgodzie z działaniami wycofującymi się z określonych przyjętych w nieodległej przeszłości rozwiązań.

Podsumowując przemyślenia związane $\mathrm{z}$ realizacją przez wprowadzone w ostatnim czasie unormowania zasady sprawiedliwości podatkowej, nie sposób pominąć szczególnej kategorii przywileju, tj. ulgi na badania i rozwój, funkcjonującego zarówno na gruncie podatku dochodowego od osób fizycznych (art. 26e-26g u.p.d.f.), jak i podatku od osób prawnych (art. 18d-18e ustawy z 15 lutego 1992 r. o podatku dochodowym od osób prawnych, t.j. Dz.U. 2017, poz. 2343). Preferencja w tym zakresie przyznawana jest podatnikom, którzy prowadzą działalność badawczo-rozwojową $(\mathrm{B}+\mathrm{R})$, i polega na tym, że koszty związane z tą aktywnością dwukrotnie wpływają u nich na wysokość podstawy obliczenia podatku dochodowego. Po raz pierwszy podatnicy ujmują określone koszty np. pracownicze w kosztach uzyskania przychodów na zasadach ogólnych, natomiast po raz drugi - przez odliczenie od podstawy opodatkowania tych samych kosztów w ramach ulgi $\mathrm{B}+\mathrm{R}$, w określonym zakresie (część lub całość, a nawet niekiedy $150 \%$ wydatków), ujętych już wcześniej przez podatnika w kosztach podatkowych. W rezultacie w obowiązującym od początku 2018 r. stanie prawnym ${ }^{77}$ przedsiębiorca może wykorzystać podatkowo konkretny wydatek kwalifikowany (dany koszt) w lącznym zakresie do 200\% jego wysokości, a nawet w szczególnych przypadkach, gdy ma status centrum badawczo-rozwojowego - do 250\%. Jednocześnie poszerzono zakres możliwych do uwzględniania ulg kosztów kwalifikowanych, które obejmują również obecnie odpisy amortyzacyjne od budynków, budowli i lokali wykorzystywanych do pracy badawczo-rozwojowej.

Powyższe oznacza, że obszar funkcjonowania omawianej preferencji został obecnie zakreślony niezwykle szeroko, co przy uwzględnieniu faktu, iż z ulgi tej korzystają najczęściej podatnicy o dużym potencjale inwestycyjnym, znajdujący się w stabilnej sytuacji gospodarczej oraz prowadzący działalność w szerokim zakresie, nakazuje się zastanowić, czy regulacja ta pozostaje w zgodzie z wymogami sprawiedliwości podatkowej. Należy bowiem zauważyć, że znowelizowane przepisy stwarzają po stronie podmiotów prowadzących działalność w zakresie $\mathrm{B}+\mathrm{R}$ łącznie $\mathrm{z}$ „podstawową” działalnością gospodarczą bardzo istotną przewagę w zakresie rozliczeń podatkowych nad podmiotami gospodarczymi niefunkcjonującymi ściśle w takim obszarze. Trzeba przy tym zaznaczyć, że względy sprawiedliwości i równości opodatkowania nie sprzeciwiają się oczywiście stosowaniu tego typu przywilejów dotyczących działal-

77 Zgodnie z art. 1 pkt 2 lit. e ustawy z 9 listopada 2017 r. o zmianie niektórych ustaw w celu poprawy otoczenia prawnego działalności innowacyjnej, Dz.U. poz. 2201. 
ności innowacyjnej, jednak należałoby przy tym dokładnie rozważyć kwestię związaną z tym, czy bardzo szeroki zakres obowiązującej obecnie ulgi:

- nie narusza konstytucyjnej zasady wolności działalności gospodarczej i równego traktowania przedsiębiorców (art. 22 Konstytucji) oraz czy

- nie skutkuje istotnym zmniejszeniem wpływów podatkowych od dużych przedsiębiorstw, uniemożliwiając przy tym skuteczną realizację celów społecznych postawionych przez państwem, choćby przez unormowania Konstytucji RP (np. jej art. 68).

\section{Podsumowanie}

Biorąc pod uwagę wskazane wyżej uwarunkowania, należy dojść do następujących wniosków. Niewątpliwie obowiązek daninowy na gruncie podatku dochodowego od osób fizycznych ma swoje konstytucyjne źródło, a w związku z tym również ocena kształtu systemu ulg, zwolnień, odliczeń, kwot wolnych i kosztów funkcjonujących w ramach tego podatku musi respektować i wspierać reguły wynikające $\mathrm{z}$ Konstytucji RP (w tym zasady wynikające z jej art. 2, art. 32 ust. 1 oraz art. $84 \mathrm{i}$ art. 217). Wszelkie działania prawodawcze w analizowanym zakresie wyznaczone są zatem zasadami, wartościami i normami konstytucyjnymi, które zabraniają tworzenia instytucji pozornych, niesprawiedliwych, nadmiernie ograniczających prawa podatnika oraz podważających jego zaufanie do państwa i stanowionego przez nie prawa ${ }^{78}$. Zasady powszechności, równości i sprawiedliwości opodatkowania są przy tym traktowane komplementarnie wobec siebie, w związku z czym również tworzenie oraz wykładnia norm podatkowych $\mathrm{w}$ zakresie systemu ulg i zwolnień w podatku dochodowym musi je rozpatrywać łącznie. Nie można przyjąć, że ulgi i zwolnienia nie mogą stanowić prawa konstytucyjnego o charakterze podmiotowym, będąc przy tym odstępstwem od zasady sprawiedliwości podatkowej. Bywa wręcz odwrotnie, ponieważ są one istotnym instrumentem kształtowania wynikającego $\mathrm{z}$ art. 84 Konstytucji obowiązku ponoszenia przez jednostkę danin publicznych, które z złożenia nie mogą być oderwane od normatywnych podstaw opodatkowania, w tym uwzględniających np. minimum egzystencji i mających swe źródło w godności człowieka. Świadczą o tym choćby unormowania dotyczące kwoty wolnej od podatku. Można nawet zaryzykować twierdzenie, że bez systemu ulg i zwolnień podatek dochodowy od osób fizycznych nie spełniałby założonego przez ustawodawcę celu, gdyż nie byłby ani racjonalny, ani też sprawiedliwy. System ulg i zwolnień nie stanowi również przywileju danego przez władzę obywatelom. Przywileju nie mogą bowiem stanowić instytucje służące powszechnie podatnikom znajdującym się w takich samych sytuacjach i na

${ }_{78}$ Wyrok TK z 8 października 2013 r., sygn. akt SK 40/12, OTK-A ZU 2013, nr 7, poz. 97. 
jednakowych zasadach, będące wyrazem podtrzymywania przez państwo wolności ekonomicznej i ekonomicznych praw jednostki, które to instytucje we współczesnych systemach prawnych urastają do rangi norm konstytucyjnych.

W rezultacie należy przyjąć, że przez system ulg i zwolnień podatek dochodowy od osób fizycznych staje się niewątpliwie w mniejszym stopniu powszechnym podatkiem dochodowym, ponieważ od wielu dochodów nie jest w ogóle uiszczany oraz w licznych sytuacjach uiszczany jest nie w pełni. Nie jest jednak zasadne twierdzenie mówiące o tym, że system ten prowadzi do wyłomu w realizacji konstytucyjnej zasady sprawiedliwości podatkowej. Jest zgoła inaczej, stosowanie ulg i zwolnień może stanowić realizację prawa konstytucyjnego o charakterze podmiotowym, urzeczywistniającego zasady sprawiedliwości, równości i powszechności opodatkowania.

Należy stwierdzić również, że obowiązujący obecnie w ramach podatku dochodowego system ulg, zwolnien, odliczeń, kwot wolnych i kosztów spełnia wymogi szeroko pojmowanej zasady sprawiedliwości, w szczególności jeśli uwzględni się zmiany wprowadzone w ostatnim czasie (np. postanowienia dotyczące kwoty wolnej od podatku). Nie oznacza to jednak, że proces zapewniania zgodności przepisów ze wspomnianą regułą został już w pełni zakończony. Istnieją bowiem sfery regulacji, które wymagają bądź to pilnych nowelizacji (np. postanowienia dotyczące „pracowniczych” kosztów podatkowych), bądź to głębszej refleksji (np. zakres stosowania 50\% kosztów dla działalności twórczej czy też właściwe ramy ulgi $\mathrm{B}+\mathrm{R}$ ), po to aby w pełni i wszechstronnie zagwarantować przestrzeganie zasady sprawiedliwości, powszechności oraz równości opodatkowania na gruncie rozliczeń z tytułu podatku dochodowego.

\section{Bibliografia}

Borszowski P., Pojęcie i elementy zobowiąania podatkowego [w:] Prawo finansowe, red. R. Mastalski, E. Fojcik-Mastalska, Wolters Kluwer, Warszawa 2013.

Bouvier M., Wprowadzenie do prawa podatkowego i teorii podatku, Wydawnictwo Konieczny i Kruszewski, Warszawa 2000.

Dauter B., Komentarz do art. 67(a) ustawy - Ordynacja podatkowa [w:] S. Babiarz i in., Ordynacja podatkowa. Komentarz, LexisNexis, Warszawa 2013.

Durczyńska M., Zakres ulg w polskim systemie podatkowym [w:] Dylematy reformy systemu podatkowego w Polsce, red. H. Dzwonkowski, J. Kulicki, Wydawnictwo Sejmowe, Warszawa 2016.

Działocha K., Uwagi do art. 84 Konstytucji [w:] Konstytucja Rzeczypospolitej Polskiej. Komentarz, t. III, red. L. Garlicki, Wydawnictwo Sejmowe, Warszawa 2003.

Dzwonkowski H., Elementy konstrukcyjne podatku w świetle art. 217 Konstytucji, „Glosa" 1999 , nr 6.

Dzwonkowski H., Gliniecka J., Prawo finansowe, C.H. Beck, Warszawa 2013.

Famulska T., Sprawiedliwość podatkowa, „Przegląd Podatkowy” 1996, nr 5. 
Gajl N., Teorie podatkowe w świecie, Wydawnictwo Naukowe PWN, Warszawa 1992.

Głuchowski J., Sprawiedliwość podatkowa: założenia teoretyczne i możliwości aplikacyjne [w:] System podatkowy. Stan, kierunki reformy, wplyw na wzrost gospodarczy, stanowisko Rady Społeczno-Gospodarczej, raport nr 36, Warszawa 1999.

Gomułowicz A., Koszty uzyskania przychodów. Zasady ogólne, „Przegląd Podatkowy” 2006, nr 5.

Gomułowicz A., Lobbistyczny aspekt tworzenia prawa podatkowego [w:] Prawo finansowe i nauka prawa finansowego na przełomie wieków, red. A. Kostecki, Zakamycze, Kraków 2000.

Gomułowicz A., Ochrona wolności i praw ekonomicznych a granice opodatkowania zasady $i$ kontrowersje, „Ruch Prawniczy, Ekonomiczny i Socjologiczny” 2005, t. LXVII, nr 3.

Gomułowicz A., Podatki a etyka, Lex Wolters Kluwer Bussines, 2013, el.

Gomułowicz A., Zagadnienia etyki w opodatkowaniu [w:] Księga pamiątkowa ku czci Profesora E. Teglera, Wydawnictwo Kameleon, Poznań 1997.

Gomułowicz A., Zasada sprawiedliwości podatkowej w orzecznictwie Trybunału Konstytucyjnego. Aspekt materialny, Dom Wydawniczy ABC, Warszawa 2003.

Gomułowicz A., Zasada sprawiedliwości w polskim systemie podatkowym, „Ruch Prawniczy, Ekonomiczny i Socjologiczny" 1989, t. LI, nr 3.

Hałajasz T., Przestrzeganie zasad podatkowych $w$ konstrukcji podatków dochodowych [w:] Finanse publiczne $w$ warunkach przekształceń w gospodarce, red. J. Sokołowski, Wydawnictwo Akademii Ekonomicznej, Wrocław 1996.

Krzywoń A., Podatki i inne daniny publiczne w Konstytucji Rzeczypospolitej Polskiej, Wydawnictwo Sejmowe, Warszawa 2011.

Kulicki J., Obecny i pożądany zakres i treść konstytucyjnej regulacji zasady władztwa podatkowego państwa w Konstytucji RP z 1997 r. [w:] Dylematy reformy systemu podatkowego w Polsce, red. H. Dzwonkowski, J. Kulicki, Wydawnictwo Sejmowe, Warszawa 2016.

Kulicki J., Przejrzystość i spójność polskiego ustawodawstwa podatkowego w ocenie respondentów badania ankietowego Biura Analiz Sejmowych, seria "Analizy BAS” nr 2(144), 2017, http://www.bas.sejm.gov.pl/analizy.php.

Leszczyńska A., Ulgi i zwolnienia podatkowe w świetle zasady sprawiedliwości podatko$w e j$, „Kwartalnik Prawa Podatkowego” 2006, nr 2.

Majchrzycka-Guzowska A., Finanse i prawo finansowe, LexisNexis, Warszawa 2011.

Mastalski R., Prawo podatkowe, C.H. Beck, Warszawa 2016.

Nykiel W., Cele i funkcje ulg i zwolnien podatkowych [w:] Regulacje prawno-podatkowe i rozwiązania finansowe. Pro publico bono. Ksiega jubileuszowa Profesora Jana Głuchowskiego, TNOiK, Toruń 2002.

Nykiel W., Ulgi i zwolnienia w konstrukcji prawnej podatku, Dom Wydawniczy ABC, Warszawa 2002.

Oniszczuk J., Podatki i inne daniny w orzecznictwie Trybunału Konstytucyjnego, Wydawnictwo Konieczny i Kruszewski, Warszawa 2001. 
Partyka A., Ekonomiczne i społeczne aspekty opodatkowania [w:] Finanse publiczne i prawo finansowe, red. A. Nowak-Far, C.H. Beck, Warszawa 2017.

Perelman Ch., O sprawiedliwości, Państwowe Wydawnictwo Naukowe, Warszawa 1959.

Presnarowicz S., Zwolnienia i ulgi uznaniowe - przesłanki rozstrzygnięć, „Przegląd Podatkowy" 1998, nr 7.

Rawls J., Teoria sprawiedliwości, Wydawnictwo Naukowe PWN, Warszawa 2018.

Rybarski R., Nauka skarbowości, Warszawa 1935, wydanie wznowione Wolters Kluwer, Warszawa 2015.

Smith A., Badania nad natura i przyczynami bogactwa narodów, Wydawnictwo Naukowe PWN, Warszawa 2015.

Szczepańska I., Opodatkowanie osób fizycznych w świetle zasady sprawiedliwości podatkowej, „Ius Novum” 2015, nr 1.

Szołno-Koguc J., Dylematy sprawiedliwości podatkowej - równość i powszechność opodatkowania a przywileje podatkowe, „Studia Ekonomiczne. Zeszyty Podatkowe Uniwersytetu Ekonomicznego w Katowicach” 2016, nr 294.

Szumlakowski R., Zasada sprawiedliwości podatkowej, seria „Acta Erasmiana” t. V, Varia, red. M. Sadowski, Wydział Prawa, Administracji i Ekonomii Uniwersytetu Wrocławskiego, Wrocław 2013.

Tegler E., Wybrane aspekty teoretyczne i praktyczne sprawiedliwości podatkowej [w:] Ksiegga jubileuszowa prof. dr Leona Kurowskiego. Podstawowe zagadnienia prawa finansowego i polityki finansowej w Polsce w latach 1989-1997, red. E. Chojna-Duch, W. Gronowski, Wydawnictwo Konieczny i Kruszewski, Warszawa 1998.

Ziembiński J., O pojmowaniu sprawiedliwości, Instytut Wydawniczy Daimonion, Lublin 1992.

\section{Orzecznictwo}

Wyrok TK z 14 grudnia 1993 r., sygn. akt K 8/93, OTK 1993, cz. 2, poz. 43.

Wyrok TK z 24 maja 1994 r., sygn. akt K 1/94, OTK 1994, nr 1.

Wyrok TK z 28 listopada 1995 r., sygn. akt K 17/95, OTK 1995, nr 3.

Wyrok TK z 29 maja 1996 r., sygn. akt K 22/95, OTK 1996, nr 3, poz. 21.

Wyrok TK z 25 listopada 1997 r., sygn. akt K 26/97, OTK 1997, nr 5-6, poz. 64.

Wyrok TK z 20 października 1998 r., sygn. akt K 7/98, OTK 1998, nr 6.

Wyrok TK z 7 czerwca 1999 r., sygn. akt K 18/98, OTK 1999, nr 5, poz. 95.

Wyrok TK z 9 listopada 1999 r., sygn. akt K 28/98, OTK 1999, nr 7, poz. 162.

Wyrok z 25 kwietnia 2001 r., sygn. akt K 13/01, OTK ZU 2001, nr 4, poz. 81.

Wyrok TK z 27 lutego 2002 r., sygn. akt K 47/01, OTK-A ZU 2002, nr 1, poz. 6

Wyrok TK z 20 listopada 2002 r., sygn. akt K 41/02, OTK-A ZU 2002, nr 6, poz. 83.

Wyrok TK z 17 listopada 2009 r., sygn. akt SK 64/08, OTK-A ZU 2009, nr 10, poz. 148.

Wyrok TK z 12 kwietnia 2011 r., sygn. akt SK 62/08, OTK-A ZU 2011, nr 3, poz. 22.

Wyrok TK z 25 kwietnia 2001 r., sygn. akt K 13/01, OTK ZU 2001, nr 4, poz. 81.

Wyrok TK z 21 czerwca 2011 r., sygn. akt P 26/10, OTK-A ZU 2011, nr 5, poz. 43.

Wyrok TK z 8 października 2013 r., sygn. akt SK 40/12, OTK-A ZU 2013, nr 7, poz. 97. 
Wyrok TK z 18 listopada 2014 r., sygn. akt K 23/12, OTK-A ZU 2014, nr 10, poz. 113. Wyrok TK z 28 października 2015 r. sygn. akt K 21/14, http://trybunal.gov.pl/s/k-2114/. Postanowienie TK z 14 lipca 2004 r., sygn. akt Ts 21/04, OTK-B ZU 2005, nr 1, poz. 19. Postanowienie TK z 22 lipca 2014 r., sygn. akt Ts 230/13, http://trybunal.gov.pl/ t/s-23013/.

Wyrok NSA z 29 lipca 2005 r., sygn. akt I FSK 77/05, http://orzeczenia.nsa.gov.pl.

Wyrok NSA z 27 października 2011 r., sygn. akt II FSK 753/10, http://orzeczenia.nsa. gov.pl.

Wyrok NSA z 16 września 2015 r., sygn. akt I GSK 100/14, http://orzeczenia.nsa.gov.pl. Wyrok NSA z 7 kwietnia 2016 r., sygn. akt I FSK 1963/14, http://orzeczenia.nsa.gov.pl. Wyrok NSA z 4 października 2016 r., sygn. akt I FSK 878/14, http://orzeczenia.nsa.gov.pl. 